\title{
An Analysis of Students' Mathematical Disposition using the Comic Media in Learning Geometry
}

\author{
Akhsanul In'am \\ University of Muhammadiyah Malang Indonesia \\ ahsanul_in@yahoo.com
}

\author{
Nur Islamiati \\ University of Muhammadiyah Malang Indonesia
}

\begin{abstract}
The objective of this current research is to describe the students' mathematical disposition using the comic media in learning mathematics, especially geometry. A mixed method using quantitative and descriptive qualitative approach was employed. The subject of this research was 32 students in State Junior High School Sape. The data were obtained through Likert Scale questionnaires. The results show that the use of the comic media in learning mathematics, especially geometry, give positive effects on the students' affective domain, namely mathematical disposition. In this study, mathematical disposition consists of several aspects: 1) Self confidence in learning mathematics and in doing mathematical problems, with the average score of 2.49, is in 'good enough' category, 2) Persistency and tenacity in doing mathematical problems, with the average score of 2.53 , is in 'good' category. 3) Curiosity in learning mathematics, with the average score of 2.49, is in 'good enough' category. 4) Appreciation of mathematical application in other fields and daily life, with the average score of 2.51 , is in 'good' category.
\end{abstract}

Keywords: mathematical disposition, comic, mathematics

\section{INTRODUCTION}

Mathematics relates to the development of a nation since it plays an important role in human life [1]. Mathematics is a branch of science studying the characteristics of abstract concepts such as numbers, geometrical forms, operations and other things dealing with reasoning [2]. Mathematics is a foundation for various fields such as science and technology, which plays various types of functional roles [3]. Therefore, it becomes one of the core subjects offered to students in all levels [3, 3].

One of the branches of mathematics taught at school is Geometry. Geometry is an important branch of mathematical education because the objective of teaching geometry is to teach students about critical thinking and problem solving, as well as encourage better understanding in other subjects. Most important, learning geometry helps students increase their level of geometric thinking abilities $[2,4,5]$. Based on the psychological point of view, geometry is the presentation of abstraction from visual and spatial experiences such as plane, pattern, measurement and mapping [6]. Meanwhile, from mathematical point of view, geometry includes approaches to problem solving in the form of pictures, diagrams, coordinate systems, vectors, and transformation [6,7].

Learning geometry gives students a comprehensive knowledge of the world, and exploring geometry may improve one's ability to solve problems, connect between mathematics and real life, and develop one's deduction abilities and proving skills [2, 7, 9]. Geometry has long been an important part of the school mathematics curriculum. It is also an essential aspect of humans' life because it helps them in determining amount or counting numbers in their day-to-day life, such as measuring land and making maps [10]. Besides, in solving mathematical problems like trigonometry, geometry knowledge is importantly needed [4]. In addition to its roles in mathematical fields, geometry is often useful in other disciplines, such as physical science (e.g. optic), geography (e.g. making a map), music (e.g. notes patterns), art (e.g. making a model), construction, architecture, farming and traffic signs. In this case, various professions like artists, contractors, designers, bricklayers, technicians, engineers in structure, and writers frequently use geometry in their works [4,7].

On the basis of the descriptions above, it can be seen that geometry is important to learn since it not only fosters students' thinking, but also supports other topics in mathematics [7]. Therefore, it is necessary for students to have good skills in geometry. Learning mathematics, especially geometry, will help to develop a cognitive aspect, which is referred to mathematical disposition in this context.

Mathematical disposition is an affective domain that plays an essential role in learning mathematics, especially geometry [11]. Without good mathematical disposition, a student will not be able to attain the expected mathematical ability or competence. Based on the national mathematics curriculum 2013, mathematics learning must cover affective, cognitive, and psychomotoric aspects, which should be developed in a balanced and simultaneous way. This is in line with the focus of the national curriculum 2013 in developing the character and education value [12].

Mathematical disposition deals with how students view and solve problems; whether they are self-confident and diligent, or have a great interest and an open-minded 
character to explore various alternatives in problem solving strategies. Mathematical disposition is value, commitment and professional ethic influencing teachers' behaviors toward students, families, fellow teachers, and other people. It also impacts on learning, motivation, professional development and teachers' growth [13]. Disposition is controlled by attitude and trust dealing with some values, including strong desire, awareness, and dedication of the students in learning mathematics and doing various activities in mathematics [11].

Some previous research on mathematical disposition has been done and found that mathematical disposition gave positive effects on students' mathematical problemsolving abilities [11]. Besides, mathematical disposition positively impacted on students' ability in understanding mathematical concepts [14]. Mathematical disposition is also one of important factors supporting students' success in learning mathematics, but students' negative perception on mathematics may decrease their mathematical disposition in learning mathematics [7].

There were some strategies used by researchers to solve problems dealing with mathematical disposition, one of which is by using learning media like comic pictures. Comic pictures are a series of pictures with specific layout reflecting the aim and the philosophy of the creator so that the message of the story will be well conveyed [15, 16]. The use of comic media was encouraged by the student preference and familiarity with the comic $[15,16]$. Another reason in using comic as the learning media is to solve problems encountered by students who have difficulties in and negative attitudes towards learning mathematics [17].
Many people including educators have been thinking that comic pictures will give bad effects on children, especially in their learning achievement [17]. Thus, comic pictures have merely been used as an entertainment for children. However, many studies revealed that comic media could solve students' problems in learning, not to mention in understanding the mathematical disposition in geometry [18, 19, 15]. The comic media used in the teaching-learning activities may arouse students' new desire and interest, improve and stimulate their learning motivation and activities, and give them psychological effects [15].

Indeed, the importance of mathematical disposition in learning mathematics, especially geometry, is inevitable. Therefore, the authors would like to investigate the students' mathematical disposition in learning geometry using the comic media, since the mathematical disposition is required in developing students' thinking abilities in geometry [7]. It is expected that strong awareness and dedication of both students and educators are present in every learning process. The results of the study are expected to help the educators develop their students' abilities not only in the cognitive and psychomotoric skills but also in their affective skills, including students' mathematical disposition in learning geometry. Lastly, the outcomes of this current study is expected to contribute to the mathematics learning at school and to change the perception of the people, especially the educators, on the use of comic media in learning.

Table 1. Aspects of self-confidence in learning mathematics and in solving mathematical problems

\begin{tabular}{|c|c|c|c|c|c|c|}
\hline \multirow[t]{2}{*}{ No } & \multirow[t]{2}{*}{ Item } & \multicolumn{4}{|c|}{ Option } & \multirow[t]{2}{*}{ Mean } \\
\hline & & SA & $\mathrm{A}$ & $\mathrm{D}$ & SD & \\
\hline \multirow[t]{2}{*}{1} & \multirow{2}{*}{$\begin{array}{l}\text { I feel glad and comfortable when comic } \\
\text { media is used during geometry learning. }\end{array}$} & 9 & 13 & 8 & 2 & \multirow[t]{2}{*}{2,90} \\
\hline & & $28,12 \%$ & $40,62 \%$ & $25 \%$ & $6,26 \%$ & \\
\hline \multirow[t]{2}{*}{2} & \multirow{2}{*}{$\begin{array}{l}\text { I try to think by myself first when I do } \\
\text { geometry problems before discussion. }\end{array}$} & 12 & 11 & 7 & 2 & \multirow[t]{2}{*}{3,03} \\
\hline & & $37,5 \%$ & $34,37 \%$ & $21,87 \%$ & $6,25 \%$ & \\
\hline \multirow[t]{2}{*}{3} & \multirow{2}{*}{$\begin{array}{l}\text { I try to answer questions asked by the } \\
\text { teacher when learning geometry. }\end{array}$} & 10 & 11 & 9 & 2 & \multirow[t]{2}{*}{2,90} \\
\hline & & $31,27 \%$ & $34,37 \%$ & $28,12 \%$ & $6,25 \%$ & \\
\hline \multirow[t]{2}{*}{4} & \multirow{2}{*}{$\begin{array}{l}\text { I am pessimistic in doing geometry } \\
\text { problems given by the teacher. }\end{array}$} & 2 & 2 & 13 & 15 & \multirow[t]{2}{*}{1,71} \\
\hline & & $6,25 \%$ & $6,25 \%$ & $40,62 \%$ & $46,87 \%$ & \\
\hline \multirow[t]{2}{*}{5} & \multirow{2}{*}{$\begin{array}{l}\text { I am not shy to rebut my classmates' } \\
\text { opinion from other groups during } \\
\text { presentation. }\end{array}$} & 8 & 10 & 11 & 3 & \multirow[t]{2}{*}{2,71} \\
\hline & & $25 \%$ & $31,25 \%$ & $34,37 \%$ & $9,37 \%$ & \\
\hline \multirow[t]{2}{*}{6} & \multirow{2}{*}{$\begin{array}{l}\text { I am shy to ask the teacher when I do not } \\
\text { understand the materials during group } \\
\text { discussion. }\end{array}$} & 0 & 4 & 14 & 14 & \multirow[t]{2}{*}{1,68} \\
\hline & & 0 & 12,5 & 43,75 & 43,75 & \\
\hline \multirow{2}{*}{\multicolumn{2}{|c|}{ Average }} & & 8,5 & 10,33 & 6,33 & 2,49 \\
\hline & & & $1,35 \%$ & $26,56 \%$ & $32,29 \%$ & 19,77 \\
\hline
\end{tabular}

\section{RESEARCH METHOD}

Quantitative and descriptive qualitative approaches was used in this study. The subject of this research was 32 students of State Junior High School 3 Sape. The data were collected through questionnaires with 4 point likert scales showing different level of agreement: strongly agree ( 4 points), agree ( 3 points), disagree ( 2 points) and strongly disagree (1 point). The questionnaires were administered to 32 students to obtain information on their mathematical disposition in using the comic media in learning mathematics, especially geometry. Data 
reduction, data presentation and conclusion drawing were done in the data analysis. The measurement of students' mathematical disposition consisted of two aspects, namely: 1) the self-confidence in learning mathematics and in solving mathematical problems; and 2) the persistence and tenacity in doing mathematical problems. The results of the analysis of the students' mathematical disposition using comic media in learning mathematics are presented in Table 1.

\section{RESULTS}

The results of the analysis revealed that the selfconfidence aspect in learning mathematics and solving mathematical problems show the average score of 2.29, which falls under 'good enough category'. There were two items showing 'low category' reflecting the students' disagreement with the item stating that they were pessimistic in doing geometry problems given by the teacher (item number 4) and were shy to ask the teacher when they did not understand the materials during group discussion (item number 6). The item with the highest score of 3.03, or under the 'good category', is the one stating that student tries to think by him/herself first when doing geometry problems before discussion.

Table 2. Aspects of persistence and tenacity in doing mathematical problems

\begin{tabular}{|c|c|c|c|c|c|c|}
\hline \multirow[t]{2}{*}{ No } & \multirow[t]{2}{*}{ Item } & \multicolumn{4}{|c|}{ Option } & \multirow[t]{2}{*}{ Mean } \\
\hline & & SA & A & $\mathrm{D}$ & SD & \\
\hline \multirow[t]{2}{*}{1} & \multirow{2}{*}{$\begin{array}{l}\text { I am glad to do geometry exercises in the } \\
\text { comic media to improve my understanding. }\end{array}$} & 14 & 13 & 5 & 0 & \multirow[t]{2}{*}{3,28} \\
\hline & & $43,75 \%$ & $40,62 \%$ & $15,62 \%$ & $0 \%$ & \\
\hline \multirow[t]{2}{*}{2} & \multirow{2}{*}{$\begin{array}{l}\text { When I find difficult geometry problems, I } \\
\text { ask my classmates. }\end{array}$} & 7 & 16 & 8 & 1 & \multirow[t]{2}{*}{2,90} \\
\hline & & $21,87 \%$ & $50 \%$ & $25 \%$ & $3,12 \%$ & \\
\hline \multirow[t]{2}{*}{3} & \multirow{2}{*}{$\begin{array}{l}\text { I give up when I am confused with } \\
\text { geometry problems. }\end{array}$} & 1 & 1 & 16 & 14 & \multirow[t]{2}{*}{1,65} \\
\hline & & $3,12 \%$ & $3,12 \%$ & $50 \%$ & $43,75 \%$ & \\
\hline \multirow[t]{2}{*}{4} & \multirow{2}{*}{$\begin{array}{l}\text { I am lazy to read comic media containing } \\
\text { geometry materials given by the teacher }\end{array}$} & 0 & 4 & 14 & 14 & \multirow[t]{2}{*}{1,68} \\
\hline & & $0 \%$ & $12,5 \%$ & $43,75 \%$ & $43,75 \%$ & \\
\hline \multirow[t]{2}{*}{5} & \multirow{2}{*}{$\begin{array}{l}\text { I write my ideas about possible answers } \\
\text { after doing and evaluating geometry } \\
\text { problems }\end{array}$} & 9 & 19 & 4 & 0 & \multirow[t]{2}{*}{3,15} \\
\hline & & $28,12 \%$ & $59,37 \%$ & $12,5 \%$ & $0 \%$ & \\
\hline \multirow{2}{*}{\multicolumn{2}{|c|}{ Average }} & 6,2 & 10,6 & 9,4 & 5,8 & \multirow[t]{2}{*}{2,53} \\
\hline & & $19,37 \%$ & $33,12 \%$ & 29,37 & $18,12 \%$ & \\
\hline
\end{tabular}

Next is the aspect of persistence and tenacity in working on mathematical problems. Table 2 shows that the aspect of persistence and tenacity in doing mathematical problems had the average score of 2.53 , or under 'good category'. There were two items showing the 'low category' reflecting the students disagreement with being frustrated when they were confused with geometry problems (item number 9) and being lazy to read the comic media containing the geometry materials given by their teacher (item number 10). The item with the highest average score of 3.28, or under 'good category' in this aspect showed that the students liked to do the exercises in the comic media to improve their understanding.

\section{DISCUSSION}

The results of the research show that the use of comic media improves the students' mathematical disposition in learning mathematics, especially geometry. Using the popular media most students are familiar with and interested in gives positive effects on their attitude and ability [15, 18]. It agrees with the aforementioned statement that the use of comic media in learning geometry may alleviate students' difficulties in understanding mathematical concepts and mathematical disposition [18, 19, 15]. Moreover, comic media may arouse new desires and interest, improve motivation and stimulate learning activities and bring positive impacts on the students' psychological conditions [15].

Students' positive attitude and confidence in dealing with mathematics may also influence their achievement in mathematics. Students need disposition that will make them become persistent when encountering more challenging problems, more responsible for their own learning, and develop their good habits in learning mathematics [11]. Therefore, it is necessary for mathematics teachers to pay attention to mathematical disposition. Clearly, students' mathematical disposition will develop if they are given a mathematical problem using a contextual problem relevant with their life.

One of the best ways to grow students' mathematical disposition is by using comic media learning mathematics, or commonly known as mathematical comic series. It can be designed according to student needs, or made relevant with the teacher's method or materials taught. Comic media combines pictures and texts in the form of picture story plot to make the information easily absorbed by the learners [19]. The design of the comic series attracts the students to read and understand the content of the media, so that students will be more interested in learning mathematics. Most important, mathematical comic series may help explain mathematical concepts and story problems, and provides an effective strategy in learning mathematics [15, 18, 19]. 


\section{CONCLUSION}

To conclude, the use of comic media in learning mathematics, especially geometry, may bring positive effects on students' affective domain, namely mathematical disposition. The data analysis reveals that each aspect of mathematical disposition contains of: 1) the feeling of self-confidence in learning mathematics and in solving mathematical problems, 2) the persistence and tenacity in doing mathematical problems; 3) the curiosity in learning mathematics, and 4) the appreciation of mathematical application in other fields and daily life. Therefore, it is suggested that teachers use comic media optimally in learning mathematics, especially geometry.

\section{REFERENCES}

[1] S. Rimbatmojo and T. A. Kusmayadi, "Profile of Visual - Spatial Intelligence In Solving Geometric of 11 th Grades Viewed From Gender Differences," vol. 2, no. 1, pp. 346-353, 2017.

[2] A. Yavuz, B. Aydin, and M. Avci, "The Effect Of The Success In Teaching Geometry Of Basic Level Education Mathematics," Eur. J. Educ. Stud., vol. 2, no. 6, 2016.

[3] N. Zezekwa, "Students' Attitudes towards their Learning of Geometry: A Survey of Bindura Urban Secondary Schools By," Greener J. Educ. Res., vol. 3, no. 8, pp. 404-410, 2012.

[4] H. Ma, D. Lee, and S. Lin, "A Study of Van Hiele of Geometric Thinking among 1 st through 6 th Graders," vol. 11, no. 168, pp. 1181-1196, 2015.

[5] Chianson, Kurumeh, and Obida, "Effect of cooperative learning strategy on students ' retention in circle geometry in secondary schools in Benue State , Nigeria," Am. J. Sci. Ind. Res., vol. 2, no. 1, pp. 33-36, 2011.

[6] J. Moss, Z. Hawes, and S. Naqvi, “Adapting Japanese on Study to enhance the teaching and learning of geometry and spatial reasoning in early years classrooms : a case study," ZDM Math. Educ., no. 47, pp. 377-390, 2015.

[7] T. Nopriana, "Disposisi Matematis Siswa Melalui Model Pembelajaran Geometri Van Hiele," J. Pendidian Mat. Mat., vol. 1, no. 2, pp. 80-94, 2015.

[8] S. Bokosmaty, J. Sweller, and S. Kalyuga, "Learning Geometry Problem Solving by Studying Worked Examples: Effects of Learner Guidance and Expertise," Am. Educ. Res. J., vol. 20, no. 10, pp. 1-27, 2014.

[9] I. Clement, O. Patience, and U. Nanna, "Effect of Improvised Instructional Materials on Students ' Achievement in Geometry at the Upper Basic
Education Level in Makurdi Metropolis , Benue State , Nigeria," Am. J. Educ. Res., vol. 2, no. 7, pp. 538-542, 2014.

[10] C. Browning, A. J. Edson, and C. Browning, "Mathematical Content Knowledge for Teaching Elementary Mathematics : A Focus on Geometry and Measurement," Math. Enthus., vol. 11, no. 2, 2014.

[11] R. Rahayu and Kartono, "The Effect of Mathematical Disposition toward Problem Solving Ability Based On IDEAL Problem Solver," Int. J. Sci. Res., vol. 3, no. 10, 2014.

[12] Suharsono, "Meningkatkan Kemampuan Pemahamn dan Disposisi Matematik Siswa SMA Menggunakan Teknik Probing Prompting," J. Ilmu Pendidik. dan Pengajaran, vol. 2, no. 3, pp. 278289, 2015.

[13] G. Almerico, P. Johnston, D. Henriott, and M. Shapiro, "Dispositions assessment in teacher education : developing an assessment instrument for the college classroom and the field," Res. High. Educ. J. Introd., vol. 10, no. 3, pp. 1-19, 2014.

[14] I. Kusmaryono and H. Suyitno, "The role of mathematical representation and disposition in improving students' mathematical power," AdMathEdu, vol. 6, no. 1, pp. 11-24, 2016.

[15] K. Nida, A. Buchori, and Y. H. Murtianto, "Pengembangan Comic Math Dengan Pendekatan Etnomatematika Pada Meteri Kubus Dan Balok Di SMP," Aksioma, vol. 8, no. 1, pp. 31-40, 2017.

[16] N. Sepriyanti and C. Tapia, "The Development of Mathematics Comics Media on Linear Equations and Linear Inequalities of One Variable," SHS Web Conf. 42, vol. 1, no. 15, pp. 1-8, 2018.

[17] Widyastuty, Mardiyana, and Saputro, “An Instructional Media using Comics on the Systems of Linear Equation An Instructional Media Using Comics on the Systems of Linear Equation," Int. Conf. Math. Sci. Educ., vol. 1, no. 20, pp. 1-6, 2017.

[18] Pardimin and S. Widodo, "Development Comic Based Problem Solving in Geometry," IEJME Math. Educ., vol. 12, no. 3, pp. 233-241, 2017.

[19] P. D. Widyastuti and R. D. Setyowati, "Pengembangan Media Pembelajaran Berbasis Komik Online Toondoo Dengan Metode Diskusi Dan Tanya Jawab Untuk Materi Geometri Datar Pada Siswa Kelas X Di Sma Negeri 5 Semarang," Pros. Semin. Mat. dan Pendidik. Mat., no. November, pp. 383-402, 2016. 